\title{
E-learning Berbasis Schoology dengan Penguatan Karakter Mandiri pada Materi Sistem Pencernaan Manusia di Kelas V SDI Ma'arif Garum Kabupaten Blitar
}

\author{
Naning Dwi*, Lilik Bintartik, Ferril Irham Muzaki \\ Universitas Negeri Malang, Jl. Semarang No. 5 Malang, Jawa Timur, Indonesia \\ *Penulis korespondensi, Surel: naningdwi04@gmail.com
}

Paper received: 3-3-2021; revised: 24-3-2021; accepted: 28-3-2021

\begin{abstract}
The purpose of this study is to produce schoology based e-learning products by strengthening the independent character of the material in the human digestive system in class V SDI Ma'arif NU Garum, Blitar, which is valid, practical, and interesting. This study uses the Borg and Gall research model. The results of the validation of material experts, media experts, and users alike 93.75 percent the category is very valid and the product can be used without revision. While practicality and attractiveness, student responses showed 100 percent of the categories were very interesting and practical. It can be concluded that school-based e-learning can be used in learning.
\end{abstract}

Keywords: schoology; e-learning; human digestive system

\begin{abstract}
Abstrak
Tujuan penelitian ini adalah menghasilkan produk e-learning berbasis schoology dengan penguatan karakter mandiri pada materi sistem pencernaan manusia di kelas V SDI Ma'arif NU Garum Kabupaten Blitar yang valid, praktis, dan menarik. Penelitian ini menggunakan model penelitian Borg and Gall. Hasil validasi ahli materi, ahli media, dan pengguna sama yaitu 93,75 persen kategori sangat valid dan produk dapat digunakan tanpa revisi. Sedangkan kepraktisan dan kemenarikan, respon siswa meunjukkan 100 persen kategori sangat menarik dan praktis. Dapat disimpulkan bahwa elearning berbasis schoology dapat digunakan dalam pembelajaran.
\end{abstract}

Kata kunci: schoology; e-learning; sistem pencernaan manusia

\section{Pendahuluan}

Bidang pendidikan tidak pernah luput dari perkembangan teknologi. Dilihat dari hal ini, ruang lingkup pendidikan akan mengalami perubahan secara bertahap yaitu pembelajaran yang mulanya adalah pembelajaran konvesional akan berubah menuju pembelajaran berbasis teknologi. Peran teknologi dalam dunia pendidikan yaitu menghasilkan beberapa program pembelajaran yang inovatif. Salah satu program tersebut yaitu e-learning. Menurut Rusman (dalam Widiantoro \& Rakhmawati, 2015) e-learning merupakan suatu pembelajaran dengan media berupa website yang telah disambungkan melalui jaringan internet. Pembelajaran meggunakan e-learning dapat dilakukan melalui schoology. Menurut Aminoto \& Pathoni dalam (Natalia, 2016) schoology adalah website yang menggabungkan antara e-learning dengan jejaring sosial. Artinya, schoology merupakan sistem pembelajaran berupa website yang termasuk ke dalam e-learning.

Penelitian pengembangan e-learning berbasis schoology dilakukan pada siswa kelas $\mathrm{V}$ SDI Ma'arif NU Garum Kabupaten Blitar. Penelitian dilakukan karena sekolah tersebut mulai menerapkan pembelajaran berbasis IT. Adanya lab komputer di sekolah dan siswa diperbolehkan membawa handphone menjadi tujuan penelitian pengembangan untuk 
menerapkan pembelajaran e-learning berbasis schoology. Penggunaan lab komputer yang belum maksimal juga merupakan salah satu masalah yang ada di sekolah. Sehingga dengan adanya pembelajaran e-learning diharapkan siswa dan guru dapat memaksimalkan penggunaan lab komputer agar pembelajaran berbasis IT terlaksana secara maksimal. Selain itu, pemahaman siswa terkait materi sistem pencernaan manusia belum merata. Sebagian siswa masih bingung dengan fungsi organ-organ pencernaan manusia dan bagaimana cara kerja organ-organ tersebut.

Pembelajaran e-learning berbasis schoology juga bertujuan untuk meningkatkan karakter mandiri pada siswa. Penggunaan schoology pada dasarnya dilakukan oleh setiap individu yang diharapkan dapat mencari ilmu pengetahuan baru dengan kemampuannya sendiri sehingga melalui pembelajaran e-learning berbasis schoology karakter mandiri dapat dibentuk dan ditingkatkan secara bertahap. Seperti pendapat Nefri (2017) karakter mandiri memiliki beberapa indikator diantaranya (1) tanggung jawab, (2) mampu bekerja sendiri, (3) menguasai keterampilan dan keahlian sesuai dengan bidang kerjanya, (4) kreatif, (5), inisiatif, (6) tepat waktu, (7) percaya diri, (8) menghargai perbedaan pendapat, (9) dapat melayani diri sendiri, (10) dapat menyelesaikan sebuah persoalan, (11) puas dengan pekerjaan yang dilakukannya (12) menyikapi masalah dengan matang.

\section{Metode}

Penelitian pengembangan dilakukan menggunakan metode Borg and Gall. Langkahlangkah penelitian menurut Sugiyono (2010) terdiri dari sepuluh langkah yaitu (1) potensi dan masalah, (2) pengumpulan data, (3) desain produk, (4) validasi produk, (5) revisi produk, (6) uji coba produk, (7) revisi produk, (8) uji coba pemakaian, (9) revisi produk, (10) produksi massal. Subjek penelitian pengembangan e-learning berbasis schoology adalah siswa kelas $\mathrm{V}$ SDI Ma'arif NU Garum Kabupaten Blitar. Instrumen pengumpul data yang digunakan berupa angket yang ditujukan kepada validator ahli materi, ahli media, pengguna dan siswa.

Pengumpulan data penelitian melalui wawancara dan angket. Wawancara digunakan untuk mengetahui potensi dan masalah di sekolah. Sementara itu angket yang diberikan kepada siswa bertujuan untuk menganalisis karakter mandiri, kemenarikan dan kepraktisan produk e-learning berbasis schoology. Angket yang diberikan kepada validator berfungsi untuk memvalidasi produk pengembangan e-learning berbasis schoology. Jenis data berupa data kuantitatif dan kualitatif. Data kuantitatif diperoleh dari hasil uji kevalidan yang dilakukan oleh ahli materi, ahli media, dan pengguna, uji kemenarikan dan kepraktisan dari siswa. Sedangkan data kualitatif diperoleh dari saran dan masukan ahli materi, ahli media, pengguna, dan siswa yang nantinya digunakan untuk memperbaiki produk agar menjadi lebih baik. Angket untuk para ahli menggunakan skala likert yang memiliki interval skala 1 sampai dengan 4. Sementara uji kemenarikan dan kepraktisan oleh siswa menggunkan skala Guttman yang memiliki interval "ya" dan "tidak".

Perolehan skor ahli materi, ahli media, dan pengguna dianalisis menggunakan rumus dari Akbar (dalam Subarkah, 2019). 
$V a h=\frac{T s e}{T s h} \times 100 \%$

Keterangan:

Vah = Validasi ahli

Tse = Jumlah skor

Tsh = Jumlah skor maksimal

Perolehan skor angket siswa dianalisis menggunakan rumus dari Arikunto (dalam (Subarkah 2019).

$P=\frac{\sum X}{N} \times 100 \%$

Keterangan:

$\mathrm{P} \quad=$ Persentase skor

$\sum \mathrm{X} \quad=$ Jumlah skor

$\mathrm{N} \quad=$ Jumlah skor maksimal

Selanjutnya hasil perhitungan dikategorikan menurut Akbar (dalam Subarkah 2019:26) dalam tabel 1 sebagai berikut.

Tabel 1. Kategori Hasil Validasi

\begin{tabular}{ccc}
\hline Tingkat Pencapaian (\%) & Kategori & Keputusan Uji \\
\hline $85,01-100,00$ & Sangat valid & Dapat digunakan tanpa revisi \\
$70,01-85,00$ & Cukup valid & Dapat digunakan, namun perlu direvisi kecil \\
$50,01-70,00$ & Kurang valid & Boleh digunakan dengan revisi besar \\
$01,00-50,00$ & Tidak valid & Tidak boleh digunakan \\
\hline
\end{tabular}

Sumber: Akbar (dalam Subarkah, 2019)

Berdasarkan tabel 1 dapat dijelaskan bawa e-learning berbasis schoology dapat digunakan jika dinyatakan valid, praktis, dan menarik apabila mendapatkan nilai di atas $70 \%$. Apabila kurang dari 70\% maka diperlukan revisi berdasarkan saran dan masukan ahli materi, ahli media, pengguna, dan siswa.

\section{Hasil dan Pembahasan}

\subsection{Hasil}

E-learning berbasis schoology divalidasi oleh ahli materi, ahli media, dan pengguna (guru). Hasil validasi disajikan pada tabel 2 .

Tabel 2. Data Hasil Validasi Ahli Materi, Ahli Media, dan Pengguna

\begin{tabular}{llccc}
\hline \multirow{2}{*}{ No. } & \multicolumn{1}{c}{ Aspek } & \multicolumn{3}{c}{ Persentase } \\
\cline { 3 - 5 } & Ahli materi & Ahli Media & Penggunna \\
\hline 1. & Ruang lingkup materi & 100 & 100 & 75 \\
2. & Kelayakan Penyajian & 100 & 100 & 100 \\
3. & Kebahasaan & 75 & 100 & 100 \\
4. & Karakter Mandiri & 100 & 75 & 100
\end{tabular}




\begin{tabular}{|c|c|c|c|c|}
\hline 5. & Kelayakan isi & & & 75 \\
\hline 6. & Tampilan schoology & & & 100 \\
\hline 7. & Gambar dan video & & & 100 \\
\hline 8. & Buku pedoman & & & 100 \\
\hline \multicolumn{2}{|c|}{ Jumlah } & 375 & 375 & 750 \\
\hline \multicolumn{2}{|c|}{ Rata-rata } & 93,75 & 93,75 & 93,75 \\
\hline \multicolumn{2}{|c|}{ Kategori } & Sangat valid & & \\
\hline \multicolumn{2}{|c|}{ Keputusan Uji } & Produk dapat & akan tan & \\
\hline
\end{tabular}

Hasil validasi ahli materi, ahli media, dan pengguna yaitu 93,75\% dengan kategori sangat valid dan produk dapat digunakan tanpa revisi.

Setelah dilakukan validasi produk e-learning berbasis schoology diuji kemenarikan, kepraktisan, dan penguatan karakter mandiri melalui uji coba skala kecil dan uji coba skala besar. Hasil dari uji kemenarikan, kepraktisan, dan penguatan karakter mandiri disajikan pada tabel 3.

Tabel 3. Data Kemenarikan, Kepraktisan, dan Penguatan Karakter Mandiri pada Uji Coba Skala Kecil dan Skala Besar

\begin{tabular}{llclll}
\hline \multirow{2}{*}{ No } & \multirow{2}{*}{ Aspek } & \multicolumn{2}{c}{ Persentase Uji Coba } & Kategori & Keputusan Uji \\
\cline { 3 - 6 } & & $\begin{array}{l}\text { Skala } \\
\text { Kecil }\end{array}$ & $\begin{array}{l}\text { Skala } \\
\text { Besar }\end{array}$ & \\
\hline 1. & Kemenarikan & 100 & 100 & Sangat menarik & Dapat digunakan \\
2. & Kepraktisan & 100 & 100 & Sangat praktis & tanpa revisi \\
3. & Penguatan karakter & 86,4 & 71 & Cukup mandiri & Dapat digunakan \\
& mandiri & & & & dengan revisi \\
& & & & & kecil \\
\hline
\end{tabular}

Dari tabel 3 diperoleh data kuantitatif hasil uji coba kemenarikan. Pada uji coba skala kecil dan skala besar, diperoleh persentase yang sama yaitu 100\%. Artinya, produk dikategorikan sangat menarik sehingga dapat digunakan tanpa revisi.

Hasil uji coba kepraktisan pada skala kecil dan skala besar, diperoleh persentase yang sama yaitu $100 \%$. Artinya, produk dikategorikan sangat praktis sehingga dapat digunakan tanpa revisi.

Hasil uji coba penguatan karakter mandiri pada uji coba skala kecil diperoleh persentase sebesar $86,4 \%$. Artinya siswa sudah memiliki tingkat kemandirian yang tinggi. Pada uji coba skala besar diperoleh persentase sebesar 71\%. Artinya siswa memiliki tingkat kemandirian yang cukup tetapi belum maksimal. 


\subsection{Pembahasan}

\subsubsection{Validitas E-Learning Berbasis Schoology dengan Penguatan Karakter Mandiri pada Materi Sistem Pencernaan Manusia di Kelas V SDI Ma'arif NU Garum Kabupaten Blitar}

Tabel 3 menunjukkan bahwa hasil validasi oleh ahli materi, ahli media, dan pengguna mendapatkan rata-rata $93,75 \%$ dengan kategori sangat valid sehingga produk dapat digunakan tanpa revisi. Nilai dari ahli materi diperoleh sebesar 93,37\% dengan kategori sangat valid dan keputusan uji dapat digunakan tanpa revisi. Aspek ruang lingkup materi diperoleh persentase sebesar $100 \%$. Materi yang dibahas meliputi alat pencernaan manusia, mekanisme sistem pencernaan manusia, dan penyakit yang menyerang sistem pencernaan manusia. Tingkat kesulitan materi sudah sesuai dengan tingkat berpikir siswa kelas V SD. Hal ini dapat terjadi karena diawali dengan analisis KD, indikator, dan tujuan pembelajaran. Sesuai dengan Permendikbud No. 24 Tahun 2016 yaitu KD mata pelajaran IPA 3.3 tentang menjelaskan organ pencernaan dan fungsinya pada hewan dan manusia serta cara memelihara kesehatan organ pencernaan manusia, sementara KD 4.3 yaitu menyajikan karya tentang konsep organ dan fungsi pencernaan pada hewan atau manusia.

Pada aspek kelayakan penyajian diperoleh persentase sebesar 100\% dimana penyajian soal sudah tersusun secara sistematis, dan terdapat buku pedoman penggunaan schoology. Buku pedoman bertujuan untuk memudahkan guru atau siswa ketika menggunakan schoology. Schoology sendiri merupakan sebuah program LMS (Learning Management System) dimana penggunaannya masih jarang diterapkan pada sekolah dasar. Seperti pendapat Aminoto \& Pathoni dalam (Natalia, 2016) schoology adalah website gabungan antara e-learning dengan jejaring sosial sehingga dibutuhkan panduan dalam penggunaannya. Jadi, adanya buku pedoman penggunaan schoology akan sangat bermanfaat.

Pada aspek kebahasaan diperoleh persentase $75 \%$ dimana bahasa yang digunakan pada produk sudah sesuai dengan pedoman umum ejaan Bahasa Indonesia (PUEBI). Penggunaan struktur kalimat pada soal-soal latihan dan kuis sudah jelas sehingga siswa mampu memahami maksud dari soal tersebut. Istilah yang digunakan sudah akurat tetapi masih terdapat beberapa kesalahan penulisan. Ahli materi menyarankan agar kesalahan penulisan tersebut diperbaiki.

Nilai dari ahli media diperoleh sebesar 93,37\% dengan kategori sangat valid dan keputusan uji dapat digunakan tanpa revisi. Aspek kelayakan isi diperoleh persentase $100 \%$ yang mencakup materi, soal-soal, dan kuis telah dimasukkan pada schoology. Kemudian tingkat kesulitan penggunaan schoology telah sesuai dengan tingkat berpikir siswa kelas V SD. Pada aspek tampilan schoology diperoleh persentase sebesar 100\% meliputi desain schoology yang terdiri dari berbagai macam fitur yang menarik. Salah satu fitur utama schoology adalah courses (kelas). Courses digunakan siswa untuk mengikuti pembelajaran. Courses yang terdapat pada schoology mencakup kegiatan kuis, video pembelajaran, forum berdiskusi, dan tugas. Selain courses, terdapat fitur-fitur lain seperti yang dikatakan Natalia (2016) meliputi 
(1) groups (grup), (2) resources (sumber), (3) recent activity (aktivitas terbaru), (4) calender (kalender), (5) Message (pesan) dan (6) People (orang-orang).

Pada aspek gambar dan video diperoleh persentase 100\%. Gambar terdiri dari organ pencernaan manusia dimana siswa disuruh untuk mengamati dan mencari apa fungsi organ tersebut, bagaimana cara kerja organ tersebut, enzim apa saja yang terdapat pada organ tersebut. Siswa merasa cukup jelas dengan gambar yang disediakan sehingga tidak mengalami kesulitan dalam memahaminya. Selanjutnya terdapat tiga video pembelajaran pada schoology. Video pembelajaran terlihat menarik dan menyenangkan karena menggunakan animasi kartun sehingga mudah untuk dipahami. Isi dari ketiga video tersebut kurang lebih sama, yang membedakan hanyalah durasi video. Pada Aspek kelayakan buku pedoman penggunaan schoology diperoleh persentase sebesar 75\% yang mencakup kemenarikan gambar, kejelasan gambar, dan petunjuk penggunaan. Kemenarikan gambar dimulai dari cover yang sudah full color dan dilengkapi dengan gambar-gambar yang menarik. Gambar diatur supaya jelas dan tidak pecah ketika dicetak. Selanjutnya petunjuk yang terdapat pada buku pedoman dibuat secara sederhana agar mudah untuk dipahami.

Sementara itu, nilai validasi dari pengguna diperoleh sebesar 93,75\% yang menilai semua aspek pada instrumen validasi. Menurut pengguna, materi sudah sesuai dengan KD, indikator, dan tujuan pembelajaran. Tingkat kesulitan dalam soal ataupun materi sedikit sulit dikarenakan sebagian siswa ada yang sudah lupa dengan materi pembelajaran sistem pencernaan. Penyajian buku pedoman disajikan secara jelas sehingga pengguna dapat memahami dan menggunakan schoology dengan mudah. Aspek kebahasaan sudah sesuai dengan pedoman umum ejaan Bahasa Indonesia (PUEBI) dan menggunakan struktur kalimat yang jelas. Penguatan karakter mandiri akan muncul dalam pembelajaran menggunakan schoology sehingga pembelajaran akan terfokus pada siswa. Sesuai dengan pendapat Rusman dalam (Widiantoro \& Rakhmawati, 2015) melalui e-learning pemahaman siswa terhadap materi tidak bergantung kepada instruktur atau guru dikarenakan siswa bisa mencari ilmu pengetahuan sendiri pada situs web e-learning (schoology).

Aspek tampilan schoology, gambar, video, dan buku pedoman menurut pengguna sudah sangat menarik dan dapat digunakan oleh siswa dengan mudah. Pembelajaran akan menjadi lebih menyenangkan dan menarik. Sehingga dapat memacu siswa untuk lebih memperhatikan pembelajaran.

Sementara itu ahli materi, ahli media, dan pengguna memberikan masukan dan saran untuk produk e-learning berbasis schoology agar menjadi produk yang lebih baik lagi. Seperti ahli materi memberikan saran jika kesalahan penulisan dalam buku pedoman penggunaan schoology harus diperbaiki. Selanjutnya, ahli media memberikan saran jika gambar yang terdapat dibuku pedoman sebaiknya lebih diperjelas lagi, penambahan shape warna merah pada tombol menu agar pembaca dapat mengetahui dengan jelas mana yang harus digunakan. Hal ini dilakukan agar pengguna nantinya dapat memahami dengan mudah langkah-langkah penggunaan schoology. 


\subsubsection{Kemenarikan E-Learning Berbasis Schoology dengan Penguatan Karakter Mandiri pada Materi Sistem Pencernaan Manusia di Kelas V SDI Ma'arif NU Garum Kabupaten Blitar}

Hasil uji coba kemenarikan produk e-learning berbasis schoology pada skala kecil dan skala besar diperoleh persentase sebesar 100\%. Kemenarikan e-learning berbasis schoology dapat dipengaruhi oleh penggunaan teknologi berupa laptop, komputer, maupun HP yang digunakan saat uji coba skala kecil dan skala besar. Menurut siswa-siswi kelas V SDI Ma'arif NU Garum pembelajaran berbasis IT sangatlah menyenangkan dan tidak membosankan bagi mereka. Siswa dapat belajar dan mencari tahu berbagai macam informasi mengenai sistem pencernaan manusia dengan cara menonton video pembelajaran yang terdapat pada schoology. Siswa dapat bertukar informasi pada forum diskusi yang sudah disediakan. Siswa dapat berlatih mengerjakan kuis untuk mengasah kemampuannya terkait materi sistem pencernaan manusia sehingga pembelajaran disini tidak terfokus pada guru melainkan pada siswa.

Sesuai dengan salah satu karakteristik e-learning menurut Widiantoro \& Rakhmawati (2015) yaitu kemandirian, artinya penyediaan waktu, tempat, pengajar, dan bahan ajar menjadi fleksibel sehingga menyebabkan pembelajaran berpusat pada siswa. Jadi dapat disimpulkan bahwa rata-rata siswa menganggap e-learning berbasis schoology yang dikembangkan sangatlah menarik. Pendapat ini dikuatkan dengan pedoman perhitungan menurut Akbar (dalam Subarkah 2019:26) jika hasil yang didapatkan berada dalam rentang 85,01\%-100,00\% termasuk kedalam kriteria sangat menarik.

\subsubsection{Kepraktisan E-Learning Berbasis Schoology dengan Penguatan Karakter Mandiri pada Materi Sistem Pencernaan Manusia di Kelas V SDI Ma'arif NU Garum Kabupaten Blitar}

Hasil uji coba kepraktisan produk e-learning berbasis schoology pada skala kecil dan skala besar diperoleh persentase sebesar $100 \%$. Cepatnya pemahaman siswa terhadap penggunaan schoology dapat dipengaruhi oleh kebiasaan siswa yang telah mengenal teknologi sejak dini sehingga siswa sudah terbiasa dengan penggunaan teknologi. Antusias siswa terhadap e-learning berbasis schoology sangat tinggi sehingga menimbulkan rasa ingin tahu yang kuat saat penggunaan e-learning berbasis schoology.

Sesuai dengan isi Permendikbud No. 22 tahun 2016 dimana pembelajaran di sekolah dasar seharusnya diselenggarakan secara interaktif, inspiratif, menyenangkan, menantang, memotivasi peserta didik untuk berpartisipasi aktif dalam mengembangkan kreativitasnya yang sesuai dengan bakat, minat dan psikologis siswa. Jadi dapat disimpulkan bahwa seluruh siswa menganggap e-learning berbasis schoology yang dikembangkan sangatlah praktis dan dapat digunakan tanpa revisi. 


\subsubsection{Penguatan Karakter Mandiri pada E-Learning Berbasis Schoology Materi Sistem Pencernaan Manusia di Kelas V SDI Ma'arif NU Garum Kabupaten Blitar}

Selain kemenarikan dan kepraktisan, terdapat aspek penguatan karakter mandiri pada produk e-learning berbasis schoology yang bertujuan untuk meningkatkan kemandirian siswa dalam melakukan pembelajaran. Hasil uji coba penguatan karakter mandiri pada skala kecil diperoleh persentase sebesar $86,4 \%$ dan skala besar $71 \%$ dan didapatkan rata-rata sebesar 78,7\%. Jika dilihat dari hasil persentase penguatan karakter mandiri masih belum maksimal dikarenakan banyak siswa yang meminta bantuan kepada orang lain ketika mengalami kesulitan untuk menyelesaikan soal-soal ataupun masalah pada schoology. Kesadaran siswa akan peningkatan karakter mandiri masih belum muncul. Diperlukan cara atau strategi yang lebih efektif agar karakteristik kemandirian bisa lebih ditingkatkan sehingga hal ini bisa sesuai dengan pendapat (Barnawi \& Arifin, 2012) jika tujuan pembelajaran itu sendiri mencakup aspek peningkatan wawasan, perilaku, dan keterampilan dengan tujuan akhirnya yaitu mewujudkan insan yang berilmu dan berkarakter.

Dengan adanya karakter mandiri, siswa diharapkan bisa percaya terhadap kemampuan yang dimiliki oleh dirinya sendiri sehingga tidak perlu untuk meminta bantuan orang lain selagi dirinya mampu melakukan hal tersebut. Hal ini sesuai dengan pengertian karakter mandiri mendiri menurut (Kemendiknas, 2011) yaitu merupakan sikap dan perilaku yang tidak mudah tergantung pada orang lain dalam menyelesaikan tugas-tugasnya. Selain itu, karakter mandiri juga dijadikan acuan sebagai standar kompetensi lulusan (SKL) yang tercantum dalam Permendikbud No. 20 tahun 2016. Setiap lulusan satuan pendidikan dasar memiliki kompetensi pada tiga dimensi yaitu sikap, pengetahuan, dan keterampilan.

\section{Simpulan}

Berdasarkan pembahasan, hasil validasi ahli materi, ahli media, dan pengguna diperoleh persentase 93,75\% dan termasuk kategori sangat valid sehingga dapat digunakan tanpa revisi. Hasil uji coba kemenarikan produk skala kecil dan skala besar diperoleh persentase sebesar $100 \%$ dan termasuk kategori sangat menarik sehingga dapat digunakan dalam pembelajaran tanpa revisi. Hasil uji coba kepraktisan produk skala kecil dan skala besar diperoleh persentase sebesar $100 \%$ dan termasuk kategori sangat praktis sehingga dapat digunakan dalam pembelajaran tanpa revisi. Penguatan karakter mandiri pada uji coba skala kecil dan skala besar mendapatkan rata-rata persentase $78,7 \%$ dengan kategori cukup mandiri sehingga harus lebih diperhatikan agar siswa terpacu untuk meningkatkan kemandiriannya dalam melakukan pembelajaran e-learning berbasis schoology.

\section{Daftar Rujukan}

Aminoto, T. P. (2014). Penerapan Media E-Learning Berbasis Schoology untuk Meningkatkan Aktivitas dan Hasil Belajar Materi Usaha dan Energi di Kelas XI SMA N 10 Kota Jambi. Jurnal Pendidikan Fisika, 8(1), 13-29.

Barnawi \& Arifin. (2012). Strategi \& Kebijakan Pembelajaran Pendidikan Karakter. Jogjakarta: Ar-ruzz Media.

Kementrian Pendidikan Nasional. (2011). Panduan Pelaksannaan Pendidikan Karakter. Jakarta: Kementrian Pendidikan Nasional Badan Penelitian dan Pengembangan Pusat Kurikulum dan Perbukuan. 
Natali, E. (2016). Pengembangan E-Learning Dengan Schoology Pada Materi Dinamika Benda Tegar. Jurnal Pendidikan.

Nefri. (2017). Ciri-Ciri Kemandirian. Diakses 29 Desember, 2019, dari Pusat Kemandirian Anak website: https://pusatkemandiriananak.com/ciri-ciri-kemandirian/

Permendikbud No. 20. (2016). Permendikbud No. 20 Tahun 2016 Tentang Standar Kompetensi Lulusan. Jakarta. Mendikbud.

Permendikbud No. 22. (2016). Permendikbud No. 22 Tahun 2016 Tentang Standar Proses Pendidikan Dasar dan Menengah. Jakarta. Mendikbud.

Permendikbud No. 24. (2016). Permendikbud No. 24 Tahun 2016 Tentang Kompetensi Dasar. Jakarta. Mendikbud.

Rusman. (2012). Belajar dan Pembelajaran Berbasis Komputer. Bandung. Alfabeta.

Subarkah, B. A. (2019). Pengembangan e-modul interaktif materi bangun datar kelas IV di MI Perwanida Kota Blitar. Universitas Negeri Malang, Jurnal Pendidikan.

Sugiyono. (2010). Metode Penelitian Administrasi. Bandung: Alfabeta

Widiantoro, R. (2015). Pengembangan Media Pembelajaran E-Learning Berbasis Schoology Pada Kompetensi Dasar Memahami Model Atom Bahan Semikonduktor Di SMKN Negeri 1 Jetis Mojokerto, Jurnal Pendidikan, 4(5), 501 - 506. 